\title{
Autotransfusión sanguínea en cirugía ortognática: no necesario
}

\section{Autologous blood transfusion in orthognathic surgery: not necessary}

\author{
F. Hernández Alfaro, R. del Rosario Regalado, D. Mair
}

Resumen: La cirugía de las deformidades maxilofaciales ha evolucionado de manera importante en las últimas décadas y el número de pacientes que reciben este tipo de tratamiento ha aumentado de forma considerable. Uno de los temas más debatidos en la literatura reciente se refiere a la necesidad de autodonación sanguinea preoperatoria. hacemos una revisión de las publicaciones relevantes en años recientes, que demuestran puntos de vista opuestos.

Palabras clave: Autotransfusión; Sangre; Cirugía ortognática.
Abstract: Surgery for maxillofacial deformities has seen important developments over the last decades and the number of patients undergoing these types of treatment has increased considerably. One of the most debated issues in the recent literature concerns the need for preoperative autologous blood donation. A revision of the relevant publications of recent years reveals opposite views.

Key words: Autotransfusión; Blood; Orthognathic Surgery.

Recibido: 20.07 .06

Aceptado: 06.10 .06

Clínica Teknon, Barcelona, España

Correspondencia:

Dr. F. Hernández Alfaro

Clínica Teknon

C/ Marquesa de Vilallonga 12, despacho 50

08015 Barcelona, España 
La cirugía de las deformidades maxilofaciales ha experimentado un desarrollo importante en las últimas décadas y el número de pacientes que se someten a este tipo de tratamientos ha sufrido un incremento considerable. Uno de los argumentos más discutidos en la literatura reciente es la necesidad de donacion de sangre autóloga previa a la intervención. Revisando las publicaciones relevantes de los últimos años podemos encontrar posturas opuestas.

Kramer observó en un estudio prospectivo sobre 1000 pacientes intervenidos mediante cirugía ortognática una incidencia del $1,1 \%$ de hemorragia severa. ${ }^{1}$ Todos los sangrados se produjeron en cirugía bimaxilar y fueron causados por laceraciones de ramas de los vasos maxilares, en la mayoría provocados por fracturas irregulares de pterigoides o durante el descenso maxilar. El autor no menciona el tiempo medio quirúrgico empleado, pero recomienda la donación de sangre autóloga de forma rutinaria para evitar episodios relevantes de anemia intra o postoperatorias y para prevenir la necesidad de donación de sangre homóloga.

Martín sugiere tras una revisión de 178 procedimientos de cirugía ortognática la necesidad de donación de sangre autóloga en el preoperatorio, asi como una relación directa entre la pérdida media de sangre durante las intervenciones y el tiempo quirúrgico. ${ }^{2} \mathrm{El}$ tiempo medio en intervenciones monomaxilares de mandíbula fue de $193 \pm 83 \mathrm{~min}$, en intervenciones monomaxilares del maxilar de $196 \pm 59$ min y en intervenciones bimaxilares de $324 \pm 81 \mathrm{~min}$. A partir del año 1998 y hasta el 2001 describieron un porcentaje de utilización de transfusiones autólogas del 35\% en los pacientes operados, pero a partir del año 1999 no se utilizaron más transfusiones en cirugía monomaxilar. El autor propone una donación de sangre autóloga de tres a cuatro unidades en cirugía bimaxilar y también en casos seleccionados con mayor riesgo en cirugía monomaxilar, por motivo médicos y jurídicos.

Nkenke en un estudio sobre 56 intervenciones de cirugía bimaxilar comparó un grupo de pacientes con donación de sangre autóloga 6 semanas antes de la intervención con un grupo control que no había realizado dicha donación. ${ }^{3}$ El valor medio de hemoglobina preoperatorio se mostró más bajo en el grupo con donación previa $(13,5 / 14,1 \mathrm{mg} / 100 \mathrm{ml})$ al igual que el valor medio de hemoglobina intraoperatorio $(11,9 / 12,8 \mathrm{mg} / 100 \mathrm{ml})$. Consideraron un valor de hemoglobina inferior a $7,5 \mathrm{mg} / 100 \mathrm{ml}$ como indicación de transfusión por lo que tres pacientes $(9,6 \%)$ del grupo con donación previa tuvieron que ser transfundidos. Ningún paciente del grupo sin donación necesitó transfusión. El tiempo medio quirúrgico no presentó diferencias significativas entre los dos grupos (208/219 min) ni tampoco el control postoperatorio de la hemoglobina $(11,0 / 11,5 \mathrm{mg} / 100 \mathrm{ml})$. El autor no aconseja la autodonación por el mejoramiento actual de las técnicas de control de sangre homóloga y por el bajo porcentaje de pacientes que precisó una transfusión en su estudio.

Ueki examinó 62 pacientes tratados quirúrgicamente por prognatismo mandibular controlando los parámetros sanguíneos. ${ }^{4}$ Estableció 4 grupos diferentes: uno tratado con osteotomías sagitales bilaterales mandibulares (BSSO), otro con osteotomías verticales de rama mandibular (IVRO), un tercero con osteotomía de LeFort I más BSSO, y un cuarto tratado con LeFort I más IVRO. La pérdida media de sangre varió entre $125,5 \mathrm{ml}$ en el grupo tratado con IVRO y 343,6
Surgery for maxillofacial deformities has seen important developments over the last decades and the number of patients undergoing these types of treatment has increased considerably. One of the most debated issues in the recent literature concerns the need for preoperative autologous blood donation. A revision of the relevant publications over recent years reveals opposite views.

In a prospective study of 1000 patients who underwent orthognathic surgery, Kramer observed an incidence of severe hemorrhaging that was $1.1 \% .{ }^{1}$ All bleeding occurred during bimaxillary surgery and it was caused by the laceration of the branches of maxillary vessels, mostly produced by irregular fractures of the pterygoid or during the descent of the maxilla. The author does not mention the average operative time, but he recommends the routine donation of autologous blood in order to avoid relevant episodes of anemia intra- or post-operatively, and for preventing the need for homologous blood donation.

After a revision of 178 orthognathic surgical procedures, Martini suggests the need for preoperative autologous blood donation, and he also noted a direct relationship between mean blood loss during surgery and operative time. ${ }^{2}$ The mean time for single-jaw surgery of the mandible was 193+/83 mins, in single-jaw surgery for the maxilla this was 196+/59 mins, and for double-jaw surgery mean time was 324+/81 mins. Between 1998 and 2001 the percentage of autologous transfusions in operated patients was $35 \%$, but as from 1999 transfusions were no longer used in single-jaw surgery. The author proposed a donation of autologous blood of three to four units for bimaxillary surgery, and in certain cases entailing greater risk in single-jaw surgery, for medial and legal reasons.

In a study of 56 double-jaw operations, Nkenke compared a group of patients who had predeposited autologous blood 6 weeks before surgery with a control non-donor group. ${ }^{3}$ The mean value of preoperative hemoglobin was lower in the predeposited blood group (13.5/14.1 mg/100 $\mathrm{ml})$ as was intraoperative hemoglobin $(11,9 / 12,8 \mathrm{mg} / 100$ $\mathrm{ml}$.) Hemoglobin values lower than $7,5 \mathrm{mg} / 100 \mathrm{ml}$ were considered to indicate the need for transfusion and, as a result, three patients (9.6\%) of the predeposit group were transfused. None of the patients in the non-donor group required a transfusion. There were no significant differences in the mean surgical times of the two groups (208/219 $\mathrm{min})$ nor in the evaluation of postoperative hemoglobin (11.0/11.5 $\mathrm{mg} / 100 \mathrm{ml})$. The author does not advise predepositing autologous blood given the increased safety of homologous blood and the low percentage of patients that required transfusions during the study.

Ueki assessed 62 patients who were treated surgically for mandibular prognathia and the blood parameters were evaluated. ${ }^{4}$ He established 4 different groups: one containing the mandibular bilateral sagittal split osteotomies (BSSO), another with the intraoral vertical ramus osteotomies (IVRO), a third with Le Fort I osteotomies combined with BSSO, and 
$\mathrm{ml}$ en el grupo tratado con LeFort I más BSSO. Ningún paciente necesitó transfusión sanguínea. La duración media de la intervención osciló entre 84,1 min en el grupo tratado con IVRO y 205,0 min en el grupo tratado con LeFort I más BSSO, encontrándose una relación estadísticamente significativa entre la duración de la intervención y que por ello la autotransfusión significativa entre la duración de la intervención y el volumen de sangre perdido. En conclusión el autor opina que en la cirugía ortognática rutinaria existe un bajo riesgo de sangrado importante y que por ello la autotransfusión sanguínea tendria que ser considerada sólo en pacientes con antecedentes médicos de riesgo.

Nath evaluó la necesidad de transfusión de sangre autóloga en 913 pacientes, de los cuales, 260 habían sido tratados mediante cirugía ortognática. ${ }^{5} \mathrm{El}$ autor no aporta datos sobre el tipo de intervención realizada. 126 de estos 260 pacientes habían realizado una autodonación previa. Encontró en 29 de los pacientes (11,15\%) tratados con cirugía ortognática la necesidad de transfundir: 26 pacientes $(10,0 \%$ del total, 20,63\% de los pacientes con autodonación) transfundidos habían realizado una autodonación previa y 3 pacientes $(1,15 \%$ del total, 2,23\% de los pacientes sin autodonación) recibieron una transfusión homóloga. El autor considera que la necesidad de transfusión está sobreestimada por el riesgo relativamente mínimo de sangrado. Dhariwal encontró revisando 115 pacientes a los que se les había practicado cirugía bimaxilar, que 9 de dichos pacientes (8\%) habían sido transfundidos con sangre homóloga. ${ }^{6}$ El tiempo medio de las intervenciones fue de $270 \mathrm{~min}$, pero hay que considerar que a 20 pacientes también se les practicó procedimientos adicionales. No encontró ninguna correlación entre la pérdida de sangre, el tiempo quirúrgico y el tipo de procedimiento empleado. El autor supone que en 5 $(55,55 \%)$ de los 9 pacientes transfundidos la transfusión no estaba indicada y que se llevó a cabo por la inexperiencia del anestesista y por el hecho de disponer de sangre homologa. En los 4 (44,44\%) pacientes restantes, la sangre fue subministrada por sangrado de vasos específicos durante la intervención y el posible sangrado postoperatorio. El autor opina que lo mas indicado para el paciente seria utilizar una combinación de estrategias para minimizar el sangrado y transfundir únicamente cuando fuese absolutamente necesario, considerando que en cirugía ortognática electiva la autotransfusión debería ser eludida. Khan realizó un estudio retrospectivo sobre 25 pacientes intervenidos mediante osteotomias bimaxilar, hallando la necesidad de transfusión de sangre homologa en un único caso (4\%). ${ }^{7}$ Concluye afirmando que ante una necesidad estimada de transfusión estimada menor de $5 \%$ no estan indicadas las pruebas con posterior reserva de sangre. Únicamente se precisarian en casos seleccionados, con valores de hemoglobina o volumen sanguineo bajos.

Gong comparó en un estudio retrospetivo 83 pacientes a los que se habia practicado cirugía bimaxilar, agrupandolos en 2 grupos. ${ }^{8}$ Uno consto de 43 pacientes, 34 de los cuales poseian una autodonación previa, y un segundo grupo de 40 pacientes sin autodonación previa pero sometidos a un protocolo para minimizar las pérdidas sanguineas mediante: un buen estudio del caso quirúrgico, técnicas anestesicas hipotensivas, cirujano experto, anestesia local con vasoconstrictor, cocainizazion de la mucosa nasal, mantenimiento del paciente en posición anti-Trendelenburg, utilización de electrocoagulación, incisiones limpias directamente a través del a fourth group that contained Le Fort I osteotomies combined with IVRO. Mean blood loss varied between $125.5 \mathrm{ml}$ in the IVRO group and $343.6 \mathrm{ml}$ in Le Fort I osteotomy with BSSO group. None of the patients required a blood transfusion. The mean time of the surgery was 84.1 mins in the group treated with IVRO and 205.0 mins in the group treated with the combined Le Fort I and BSSO. A statistically significant correlation was found between the duration of the surgery and the volume of blood lost. The author concludes that there is little risk of marked bleeding in routine orthognathic surgery, and that blood transfusions should be considered only for high-risk patients.

Nath evaluated the need for autologous blood donation in 913 patients, of whom 260 had been treated by means of orthognathic surgery. 5 The author does not provide data on the type of surgery carried out. 126 of these 260 patients had undergone preoperative autologous blood donation. He found that 29 patients (11.15\%) who underwent orthognathic surgery required transfusions: 26 transfused patients (10.0\% of the total, $20.63 \%$ of the autologous blood donors) had previously undergone autologous blood donation, and 3 patients (1.15\% of the total, $2.23 \%$ of the non-donor patients) received homologous transfusions. The author considered the need for transfusion is overestimated given the relatively small risk of bleeding.

In his revision of 115 patients, Dhariwal found of the patients who had undergone bimaxillary surgery, 9 patients (8\%) were transfused with homologous blood. ${ }^{6}$ The mean operative time was 270 mins, but it should be taken into account that 20 patients had additional procedures. No correlation was found between blood loss, surgical time and the type of procedure used. The author is of the belief that in 5 (55.55\%) out of the 9 transfused patients, the transfusion was inappropriate, and that this was carried out because the anesthetist was inexperienced, and due to the fact that homologous blood was available. In 4 (44.44\%) of the remaining patients, the blood was supplied as a result of bleeding of specific vessels during the surgery and possible postoperative bleeding. The author is of the opinion that, for the patient, what is most indicated is the use of a combination of strategies for minimizing bleeding, and for transfusions to be carried out only when absolutely necessary. He considered that in elective orthognathic surgery autotransfusions should be avoided.

Khan carried out a retrospective study of 25 patients who underwent bimaxillary osteotomies. He found that in just one case (4\%) was there need for a transfusion of homologous blood.? He concluded that, when faced with an estimated transfusion requirement of less than 5\%, testing and banking blood should not be indicated. Only in selected cases would this be necessary, if hemoglobin and blood volume levels are low.

Gong compared a retrospective study of 83 patients who had undergone bimaxillary surgery, separating them into two groups. ${ }^{8}$ One group contained 43 patients, 34 of whom 
periostio, y taponamiento con gasas de campos quirúrgicos abiertos. El volumen de sangre pérdida durante la intervención fue de $899 \mathrm{ml}$ en el grupo primero y de $403 \mathrm{ml}$ en el grupo segundo. El $37 \%$ de los pacientes del primer grupo recibió una transfusión y ninguno del segundo grupo. El autor considera que la transfusión o autodonación solo debe ser considerada en casos seleccionados con patología previa preexistente.

Yu evaluó en su estudio prospectivo sobre 29 pacientes sometidos a cirugía ortognática la pérdida sanguinea intraoperatoria en correlación con el tiempo quirúrgico. ${ }^{9}$ Ocho pacientes $(27,58)$ tratados solo con cirugía monomaxilar (el autor no distingue maxilar o mandíbula) tenían una pérdida media de sangre de 266,3 $\mathrm{ml}$ con un tiempo quirúrgico medio de 169,9 min. Veintiun pacientes $(72,41 \%)$ tratados con cirugía bimaxilar tenían una pérdida sanguinea media de $751,4 \mathrm{ml}$ con un tiempo quirúrgico medio de 296,4 min. El autor encuentró una correlación estadísticamente significativa entre el tiempo quirúrgico y la pérdida sanguinea.

Umstadt analizó en un estudio retrospectivo sobre 438 pacientes tratados con cirugía ortognática la necesidad de transfusión sanguinea. ${ }^{10} \mathrm{El} 1,55 \%$ de los pacientes operados mediante osteotomía del maxilar y el 3,03\% de los pacientes operados mediante osteotomía bimaxilar tuvieron que ser transfundidos con sangre homologa. Ningún paciente operado solamente con osteotomía mandibular necesitó transfusión. Como indicación de la transfusión se tomó un valor postoperatorio de hemoglobina inferior a 7,5 mg/ $100 \mathrm{ml}$. El autor afirma que la autodonación preoperatoria no esta indicada porque el porcentaje de la probabilidad de transfusión encontrado es inferior al 10\%, que indica la normativa alemana.

En casos de necesidad, una transfusión de sangre autóloga tiene como ventajas la eliminación el riesgo de una transmisión viral y reacciones imunológicas como hemolisis, fiebre o reación alérgica. ${ }^{11}$ Además disminuye el riesgo de infecciones postoperatorias. Los costes de los programas de administración de sangre autologa, unidos al alto porcentaje de infrautilización de dichos unidades, la anemia y la hipovolemia postdonación representan las desventajas de esta técnica.

A pesar de ello, la necesidad de transfusión en cirugía ortognática debería ser cuestionada a la vista de la baja incidencia de sangrados importantes en gran parte de la literatura revisada. La decisión de una autotransfusión debe considerar sobretodo el nivel y la duración esperados de la anemia, el tiempo quirúrgico y la probabilidad de una pérdida importante de sangre. ${ }^{12}$

Una completa coagulación durante la intervención para prevenir sangrados e imposible por la extensa vascularización en la región maxilofacial. Se pueden emplear varias técnicas para el control del sangrado. La más notable es la utilización de técnicas anestésicas hipotensivas, que mantienen la presión arterial media en 55 y $60 \mathrm{mmHg}$.

Una hipotensión bien controlada reduce la pérdida de sangre un 40 a $50 \% .^{13}$ En estos casos es fundamental una buena cooperación entre los cirujanos y los anestesistas, que conocen bien los momentos dolorosos y por tanto hipertensos de la cirugía. Una adecuada analgesia al inicio de la intervención por parte del cirujano con adrenalina y durante las osteotomías por parte del anestesista, previenen dichos momentos de estrés intraoperatorio para el paciente. Las dosis de fármacos anestésicos para mantener una hipotensión controlada durante la cirugía ortognática, se pueden mane- had previously autodonated blood, and the second group contained 40 patients who had not autodonated blood previously and who were subjected to a protocol to minimize blood loss by means of: a thorough evaluation of the surgical case, hypotensive anesthetic techniques, expert surgeon, local anesthesia with a vasoconstrictor, cocainization of the nasal mucosa, maintaining the patient in an antiTrendelenburg position, use of electrocoagulation, clean incisions directly through the periosteum, plugging open surgical fields with gauze. The volume of blood lost during surgery was $899 \mathrm{ml}$ in the first group and $403 \mathrm{ml}$ in the second group. $37 \%$ of patients in the first group received a transfusion and none in the second group. The author considers that transfusion or self-donation should only be a consideration in selected cases with preexisting pathology.

In a prospective study of 29 patients undergoing orthognathic surgery, Yu evaluated intraoperative blood loss in relation to surgical time. ${ }^{9} 8$ patients (27.58) treated only with single-jaw surgery (the author does not make any distinction between the maxilla and the mandible) had a mean blood loss of $266.3 \mathrm{ml}$ and a mean operative time of 169.9 mins. 21 patients (72.41\%) who underwent double-jaw surgery had a mean blood loss of $751.4 \mathrm{ml}$ with a mean operative time of 296.4 mins. The author found a statistically significant correlation between operative time and blood loss.

In a retrospective study of 438 patients who underwent orthognathic surgery, Umstadt analyzed the need for blood transfusions. ${ }^{10} 1.55 \%$ of patients undergoing maxillary osteotomies and $3.03 \%$ of patients undergoing bimaxillary osteotomies required a transfusion of homologous blood. None of the patients undergoing just a mandibular osteotomy required a transfusion. A postoperative value of hemoglobin that was lower than $7.5 \mathrm{mg} / 100 \mathrm{ml}$ was considered indicative of the need for a blood transfusion. The author affirms that autologous blood donation before surgery is not necessary because the percentage probability for transfusion that was found was lower than the 10\% indicated by German regulations.

If the need arises, autologous blood transfusion has the advantage of eliminating the risk of transmitting a virus and of immunological reactions such as hemolysis, fever or allergic reaction. ${ }^{11}$ Also, the risk of postoperative infection is reduced. The cost of the programs for administering autologous blood together with the high percentage of underuse of these units, anemia and hypovolemia after the donation, represent the disadvantages of this technique.

In spite of this, the need for transfusions in orthognathic surgery should be questioned in view of the low incidence of marked bleeding in a large proportion of the literature revised. Deciding on an autotransfusion should take into account the level and expected duration of the anemia, surgical time and the probability of considerable loss of blood. ${ }^{12}$

Complete coagulation during the operation in order to prevent bleeding is impossible given the extensive vascu- 
jar gracias a las últimas tecnologías como el indice bispectral (BIS). ${ }^{14}$ EI BIS permite una analgesia y sedación muy profunda, con una hipotensión controlada, evitando sufrimiento neuronal.

Menos sangrados significan un campo operatorio limpio con buena visión, reducción de complicaciones intraoperatorias, reducción del tiempo quirúrgico y menos necesidades de transfusiones de sangre.

Kurian ha elaborado un protocolo valido para disminuir la pérdida sanguinea, manteniendo el paciente en una posición semisentada de unos 20-30 grados durante la cirugía, y la presión arterial media baja, utilizando ácido tranexamico IV en el perioperatorio, y ligando de forma electiva los vasos palatinos para prevenir la complicación postoperatoria inmediata del sangrado. ${ }^{15}$ La cauterización y la ligadura de dichos vasos intraoperatoria no interfiere en la revascularización del paladar o en la osificación de las fracturas. ${ }^{16}$ Con este protocolo se consigue disminuir el retorno venoso, bajar el gasto cardíaco y la presión arterial media.

Otras nuevas tecnologías reducen el tiempo quirúrgico y así el tiempo de sangrado.

Una buena preparación y estudio del caso utilizando cirugía sobre modelos, cirugía virtual en tres dimensiones y simulación de los tejidos blandos prepara al cirujano a la situación que va a encontrar en quirófano y disminuye la necesidad de improvisar gestos quirúrgicos durante el procedimiento. ${ }^{17}$

También la reducción de los tiempos quirúrgicos en cirugía ortognática, permite en ocasiones practicarla casi en régimen ambulatorio. ${ }^{18}$

Un cirujano experto con ayudantes y instrumentistas bien instruidas sobre los movimientos intraoperatorios también reduce considerablemente el tiempo quirúrgico y evita contratiempos como la sección de vasos sanguíneos, el desgarro de tejidos blandos, etc.

En cuanto a nuestra propia experiencia, entre marzo de 1994 y marzo del 2006, hemos realizado 857 procedimientos de cirugía ortognática. De ellos 513 fueron bimaxilares, y 344 monomaxilares. En esta serie no están incluidas las expansiones del maxilar asistidas por cirugía ni las mentoplastias como procedimientos aislados. En ninguno de estos casos ha sido necesario practicar una tranfusión sanguínea.

Entre Mayo de 2005 y Mayo de 2006 hemos evaluado de manera prospectiva 163 pacientes consecutivos intervenidos de cirugía ortognática (103 bimaxilares, 60 monomaxilares). Hemos recogido los valores de pérdida hemática en cc y el tiempo quirúrgico de cada intervención.

En las cirugías monomaxilares, la perdida hemática media intraoperatoria fue de $93 \mathrm{cc}$ (rango 45-179). El tiempo quirúrgico medio en estos procedimientos fue de $47 \mathrm{~min}$ (rango 32-74).

En cuanto a las cirugías bimaxilares, la pérdida hemática media fue de 167 cc (rango 145-260). El tiempo quirúrgico medio fue de 83 min (rango 59-128).

En los protocolos contemporaneos para las distintas especialidades, la donación de sangre autóloga preoperatoria y su posterior transfusión se recomienda en cirugía invasiva electiva con riesgo incrementado de pérdida sanguínea importante. ${ }^{19}$ Cuando la cirugía ortognática es una intervención rutinaria, practicada como cirugía electiva en pacientes jóvenes y sanos, y con la aplicación de técnicas y protocolos que disminuyen el tiempo quirúrgico y el sangrado, no se precisa en nuestra opinión la autotransfusión sangui- larization of the maxillofacial region. Various techniques can be used for controlling bleeding. Of note is the use of hypotensive anesthetic techniques that maintain a mean arterial blood pressure of 55 to $60 \mathrm{mmHg}$. Well-controlled hypotension reduces blood loss by 40 to $50 \% .^{13}$ In these cases, close cooperation between surgeons and anesthetists who are familiar with the more painful moments of the operation and also those with hypertension, is fundamental. The administration of adrenalin and suitable analgesic agents at the start of the operation by the surgeon, and during the osteotomies by the anesthetist, prevent these moments of intraoperative stress for the patient. The dosage of anesthetic drugs for maintaining controlled hypotension during orthognathic surgery can be monitored as a result of the latest technology such as the bispectral index (BIS). ${ }^{14}$ The BIS permits very strong analgesic medication and deep sedation. Hypotension is controlled and neuronal suffering is avoided. Less bleeding signifies a cleaner surgical field with better vision. Intraoperative complications and surgical time are reduced and there are fewer needs for transfusions.

Kurian elaborated a valid protocol for reducing blood loss, by maintaining the patient in a semi-sitting position of 20-30 degrees during the surgery, with arterial blood pressure medium low, using tranexamic acid IV during the perioperative period, and elective ligation of the palatine vessels in order to prevent immediate postoperative bleeding complications. ${ }^{15}$ Intraoperative cauterization and ligation of these vessels does not interfere in the revascularization of the palate or in the ossification of fractures. ${ }^{16}$ With this protocol venous return is diminished, cardiac output is reduced and a mean arterial blood pressure is achieved.

Other new technologies reduce surgical time and as a result bleeding time. Good preparation and case studies using surgery on models, 3D virtual surgery and soft tissue simulation, prepares the surgeon for what he will encounter in the operating room, while reducing the need for improvising surgical acts during the procedure. ${ }^{17}$

Also, the reduction of surgical time in orthognathic surgery allows this to be carried out practically on an outpatient basis. ${ }^{18}$ An expert surgeon with instrument nurses and assistants that have been well-trained with regard to intraoperative movements, also reduces surgical time considerably, while setbacks such as the sectioning of blood vessels and the tearing of soft tissue, etc. are avoided.

With regard to our experience, between March 1994 and March 2006 we carried out 857 orthognathic surgery procedures. Of these, 513 were double-jaw and 344 singlejaw. In this series, surgery-assisted maxillary expansion was not included, nor mentoplasties or isolated procedures. In none of these cases was carrying out blood transfusions necessary.

Between May 2005 and May 2006, we evaluated in a prospective fashion 163 consecutive patients who underwent orthognathic surgery (103 double-jaw, 60 single-jaw). We recorded the hematic loss values in cc and operative time 
nea. Creemos que la transfusión tiene sentido para salvar la vida o prevenir deterioro, pero no de manera profiláctica para inducir un recuperación más rápida postoperatoria. ${ }^{20}$ Una posible autodonación tiene que ser considerada solo en aquellos pacientes con antecedentes clínicos predictores de pérdida sanguínea importante durante la cirugía o tras tiempos quirúrgicos prolongados.

\section{Bibliografía}

1. Kramer FJ, Baethge C, Swennen G, Telowitz T, Schulze A, et al. Intra- and perioperative complication of de lefort i osteotomy: A Prospective Evaluation of 1000 Patients. J Craniofac Surg 2004;15:971-7.

2. Martini M, Steffens R, Appel T, Berge S. Preoperative autologous blood donation in orthognathic surgery. Mund Kiefer Gesichtschir 2004;8:376-80.

3. Nkenke E, Kessler P, Wiltfang J, Neukam FW, Weisbach V. Hemoglobin value reduction and necessity of transfusion in bimaxillary orthognathic surgery. J Oral Maxillofac Surg 2005;63:623-8.

4. Ueki K, Marukawa K, Shimada M, Nakgawa K, Yamanoto E. The assessment of blood loss in orthognathic surgery for prognathia. I Oral Maxillofac Surg 2005;63:360-8.

5. Nath A, Pogrel MA. Preoperative autologous blood donation for oral and maxillofacial surgery: an analysis of 913 patients. J Oral Maxillofac Surg 2005;63:347-9.

6. Dhariwal DK, Gibbons AJ, Kittur MA, Sugar AW. Blood transfusion requirements in bimaxillary osteotomies. Br J Oral Maxillofac Surg 2004;42:231-5.

7. Khan MS. Blood loss in orthognathic procedures - is there an indication to cross match? Oral Surg Oral Med Oral Pathol Oral Radiol Endod 2003;96:655-6.

8. Gong SG, Krishnan V, Waack D. Blood transfusions in bimaxillary orthognathic surgery: are they necessary? Int J Adult Orthodon Orthognath Surg 2002;17:314-7.

9. Yu CN, Chow TK, Kwan AS, Wong SL, Fung SC. Intra-operative blood loss and operating time in orthognathic surgery using induced hypotensive general anaesthesia: prospective study. Hong Kong Med J 2000;6:307-11.

10. Umstadt HE, Weippert-Kretschmer M, Austermann KH, Kretschmer V. Need for transfusions in orthognathic surgery. No general indication for preoperative autologous blood donation. Mund Kiefer Gesichtschir 2000;4:228-33.

11. Vanderlinde ES, Heal JM, Blumberg N. Autologous transfusion. BMJ 2002;324:7725 .

12. Lanigan DT, Hey JH, West RA. Major vascular complications of orthognathic surgery. J Oral Maxillofac Surg 1990;48:561-73.

13. Schaberg SJ, Kelly JF, Terry BC, Posner MA, Anderson EF, Blood loss and hypertensive anaesthesia in oral-facial corrective surgery. J Oral Surg 1976;34:147-56.

14. Caverni V, Rosa G, Pinto G, Tordiglioni P, Favaro R. Hipotensive anestesia and recovery of cognitive function in long-term craneofacial surgery. J Craniofac Surg 2005;14:531-6.

15. Kurian A, Warth-Booth P. Blood transfusion and orthognathic surgery - a thing of the past? Br J Oral Maxillofac Surg 2004;369-70.

16. Bell WH, You ZH, Finn RA, Fields RT. Wound healing after multisegmental LeFort I osteotomy and transection of the desceding palatine vessels. J Oral Maxillofac Surg 1995;53:1425-33.

17. Hernandez Alfaro F, Mair D, Marti C, Biosca MJ. Planificación virtual y diseño de férulas Cad/Cam en cirugía ortognática ¿Una nueva era? Rev Esp Ortod 2005.

18. Raffaini M, Hernández Alfaro F, Ghilardi R, García A. The sagittal mandibular osteotomy under local anesthesia and intravenous sedation: four years of multicenter experience. Int J Adult Orthod Orthognath Surg 2002,4:267-271.

19. National Heart, Lung and Blood Institute Expert Panel on ther Use of Autologous Blood: Transfusion alert: Use of Autologous Blood. Transfusion 1995;35:703.

20. NHS Executive. Better blood transfusion. London: Department of Health; 1998 [HSC 1998/224]. of each intervention. In single-jaw surgery, mean intraoperative hematic loss was $93 \mathrm{cc}$ (with a range of 45-179). Mean operative time for these procedures was 47 mins (with a range of 32-74). With regard to double-jaw surgery, mean hematic loss was $167 \mathrm{cc}$ (with a range of 145-260). Mean surgical time was 83 mins (with a range of 59-128).

In the current protocols for different specialties, the preoperative donation of autologous blood and its posterior transfusion is recommended for invasive elective surgery with an increased risk of considerable blood loss. ${ }^{19}$ When orthognathic surgery is a routine intervention, and practiced as elective surgery in young, healthy patients, and when techniques and protocols are applied that reduce surgical time and bleeding, autotransfusions are not necessary in our opinion. We believe that transfusions make sense for saving lives or for preventing deterioration, but not in a prophylactic manner for inducing faster postoperative recovery. ${ }^{20}$ The possibility of self-donation should be considered only for those patients with a clinical history that is indicative of considerable blood loss during surgery or after prolonged surgical time. 